\title{
Ecclesia semper reformanda: Protestant Principle and Church Renewal
}

\author{
Professor Werner G. Jeanrond
}

\begin{abstract}
Paul Tillich's dialectics of "Protestant principle" and "Catholic substance" acknowledges the need to question any form of embodiment and inculturation of Christian faith in the transcendent and sovereign God, i.e. it acknowledges the necessity of both continuing church renewal and continuing religious and cultural embodiment of the Christian gospel. This article explores the theological potential of these concepts with regard to both the eschatological nature of Christian faith praxis and the mulitireligious universe in which Christian hope for God's coming reign must articulate itself today.
\end{abstract}

Key words: Protestant principle - Catholic substance - church reform Reformation - love - hope - eschatology - Tillich - Barth - interreligious encounter.

\section{Introduction}

Every generation of Christians faces the challenge to renew the personal and communal forms of its faith praxis in the light of critical and self-critical reflections on the central aspects of its faith. When we approach this challenge today, two related procedures present themselves to us: we could look back and try to establish criteria of orthodoxy which might be able to help us distinguish between right and wrong developments in Christian history, or we could look forward and consider ways of examining our eschatological vocation and praxis. In other words, we might wish to concentrate first and foremost on Christian beginnings, developments and past reforms, or we might wish to reflect more on Christian visions of the end of human existence in this universe. Of course, there need not be any conflict between these approaches. Rather, both approaches are necessary for a theological examination of Christian faith praxis today. For what could we ever know about Christian vocation and expectation without going back to past praxis and reflections on Christian beginnings and Christian vocation? In any case, it seems important 
for us to become conscious of why we do what when we consider ways of renewing our personal and ecclesial faith praxis today.

The global context for reflecting on church renewal today differs significantly from the regional context for church reform in sixteenth century Europe. Our horizon is no longer congruent with Martin Luther's or Jean Calvin's eurocentric worldview. Luther, Calvin and the other reformers challenged disturbing developments, claims, forms and pretensions of Christian institutional leadership and sacred mediation. Of course, even today ecclesial developments, forms of Christian discipleship and leadership, and hierarchical pretensions and failures need to be examined and challenged. However, the energy for church reform and renewal can no longer come only from internal debates on criteria of orthodoxy and from comparisons between certain branches of the Christian church, i.e. between particular parts of the one body of Christ. Rather, the entire body of Christ is called to witness to its eschatological vocation in this universe; a universe which all Christians believe is willed, created and sustained by God. Thus, the ultimate concern of Christian discipleship must never be reduced to either individualist or denominational salvation projects; rather it will always need to link our respective personal and denominational journeys and salvific expectations with the larger vision of God's creative and reconciling project in this universe.

In view of this faith in God's dynamic project, which never involves less than caring for each living and dead person in this universe, yet which always transcends any purely individualist concern, and in view of the universal dimensions of Christian eschatology, perspectives on renewal ought not to be restricted to the mere implementation of past models of being church. Hence, if Protestant churches were content with merely applying sixteenth century ecclesial paradigms on today's search for appropriate forms of Christian discipleship, they would willingly reduce their communities to some form of mausoleum. Looking at past developments in the Christian church can never replace our own responsibility of searching for always more adequate ways of responding to God's invitation in Jesus Christ to open ourselves for God's transformative presence in our lives and times. Needless to say, we can always learn from previous generations of Christians in terms of how they have attempted to respond, and how they may have failed to respond, to God's invitation to help building the body of Christ in the Spirit. Against this background, the churches of the Reformation, as indeed any other group engaged in Christian praxis in this universe, may be able to teach us today some important lessons about how to tackle the future, a fu- 
ture which we share with all men, women and children in this universe.

Responding to Peter Widmann's invitation to reflect on reformation and deformation in Christian discipleship, in this article I wish to discuss the potential of a "Protestant principle" for theological thinking about church reform. Moreover, I would like to initiate a discussion of the possibility of evoking such a principle in the multifaceted encounter between Christians and members of other religious traditions. And finally, I wish to offer some reflections on the Christian eschatological vocation as the appropriate horizon for continuing debates on church renewal.

\section{The Protestant Principle}

Karl Barth's theology represents one among recent proposals for church reform that have emerged from within the legacy of the Protestant Reformation. Barth was keenly aware of the need to apply both an eschatological perspective on theology and church. Already in the second edition of his Letter to the Romans (1922), he argued: "If Christianity be not altogether thoroughgoing eschatology, there remains in it no relationship whatever with Christ. Spirit which does not at every moment point from death to the new life is not the Holy Spirit." ${ }^{1}$ However, for Barth eschatology implied solely a Christian vision of the purpose and end of life. Possibly, Barth's very late answer to the question of whether he expects to meet his loved ones again on the other side of death, "Not only my loved ones", points to a somewhat larger horizon. ${ }^{2}$

In one way, of course, this late statement demonstrates how Barth remained faithful to his life-long defence of God's sovereignty. The eschaton is God's sovereign privilege and must never be reduced to

1. Karl Barth, The Epistle to the Romans, trans. (from the $6^{\text {th }}$ edn) Edwyn C. Hoskyns (Oxford: Oxford University Press 1968), 314. Cf. the German original: Karl Barth, Der Römerbrief, 2nd edition [1922] (Zurich: Theologischer Verlag 1978), 298: "Christentum, das nicht ganz und gar und restlos Eschatologie ist, hat mit Christus ganz und gar und restlos nichts zu tun. Geist, der nicht in jedem Augenblick der Zeit aufs neue Leben aus dem Tode ist, ist auf alle Fälle nicht der heilige Geist."

2. For one version of this anecdote see Eberhard Busch, "Eine Reformierte Stimme", Letter from the Karl Barth-Archives, Nr 4, 10. Dezember 2002, 6-7. For a reference to Barth's a priori judgment that other religions lacked faith see also Kenneth Cracknell, Mission und Dialog: Für eine neue Beziehung zu Menschen anderen Glaubens, trans. Ulrike Berger (Frankfurt/M.: Lembeck 1990), 110 . 
some form of human project. Worship of the one true God, maker of heaven and earth, ought to be directed to this mysterious God and not to whatever sort of wishful and illusory projections we human beings might harbour. Barth's radical defence of God's divinity mirrors much of Jewish and Muslim concerns, although Barth did not explore this link in any depth.

In any case, Barth's approach was sharpened not only through his struggle with Friedrich Schleiermacher and other theologians that had been upgrading and profiling human experience, but also through his struggle with Ludwig Feuerbach's critique and inversion of human projection in religion. Barth summed up Feuerbach's concern in this way: "Religion exists. Religion is possible and necessary. But it is man who is the beginning, the middle and the end of religion - man and man alone. "3 Insisting on protecting God's sovereignty and God's incarnation in Jesus Christ against the pretensions of such religion, Barth approached this task suspicious of all religious dimensions, of all attempts to mediate between God and culture. One could argue that Barth's version of the Protestant principle aimed at defending God's divinity and the eschatological nature of Christian faith.

However, Barth's version of the Protestant principle showed no respect for what Paul Tillich, who coined the phrase "Protestant principle", named "Catholic substance", i.e. "the concrete embodiment of the Spiritual Presence". For Tillich, the Protestant principle on its own is not enough; "it needs the 'Catholic substance", while the Protestant principle itself remains the "criterion of the demonization (and profanization) of such embodiment. It is the expression of the victory of the Spirit over religion." ${ }^{4}$ However, the concrete embodiment of the gospel is as necessary as is its perennial challenge in the light of the gospel.

The Irish theologian Gabriel Daly presents the relationship between Protestant principle and Catholic substance in this way:

Catholic substance is necessary because we necessarily live in the cultural webs we have woven for ourselves and because God's presence and ac-

3. Karl Barth, Protestant Theology in the Nineteenth Century: Its Background \& History, trans. Brian Cozens, John Bowden et al. (London: SCM; 1972), 536. Cf. the German original: Karl Barth, Die protestantische Theologie im 19. Jahrhundert: Ihre Vorgeschichte und ihre Geschichte, 4th edn (Zurich: Theologischer Verlag 1981), 486: "Es gibt Religion. Religion ist möglich und notwendig. Aber der Mensch ist der Anfang, der Mittelpunkt und das Ende der Religion: der Mensch und nur der Mensch.”

4. Paul Tillich, Systematic Theology, vol. 3 (Chicago: University of Chicago Press 1963), 245. 
tion are mediated through them. It is dangerous because we are also natural idolators. John Calvin in the Institutes claims that the human mind is a "perpetual factory of idols" [11.i.ii.8]. That is why according to Tillich we need the protestant principle at every turn. ${ }^{5}$

Hence, we must not only speak of reformation and deformation with respect to the Protestant Reformation of the sixteenth century, but we must also become aware of the basic human dilemma, i.e. that we always are faced with idols and icons when dealing with God and God's relationship with us human beings. In this regard Peter Widmann has helpfully observed that the concern of reformation always remains a challenge to all forms of Christian discipleship and praxis and must not be located exclusively in the events and figures of sixteenth century Europe. To relate God and world without confusing the one with the other is a lasting challenge of Christian theology and praxis.

Unlike Karl Barth, Paul Tillich was very clear about the need to apply the Protestant principle also on biblical interpretation.

Protestant theology protests in the name of the Protestant principle against the identification of our ultimate concern with any creation of the church, including the biblical writings in so far as their witness to what is really ultimate concern is also a conditioned expression of their own spirituality. ${ }^{6}$

Tillich thus explicitly affirms the status of the Bible as a book of the church, and not as a book outside of the church. Moreover, he submits all aspects of church life and organization to this necessary and radical Protestant critique (cf. Tillich 1963, 176).

Hence, the Protestant principle must be applied to all aspects of church life. It points to the fallibility of all religious institutions and hierarchies. "[T]he Protestant principle of the 'fallibility' of all religious institutions and the consequent protest against the infallible place in history, the cathedra papalis, or the Protestant principle of the 'priesthood of all believers' and the consequent protest against a priesthood which is separated from the laymen and which represents a sacred degree in a divine-human hierarchical structure", these Protestant principles are for Tillich matters of ultimate concern, whereas

5. Gabriel Daly, O.S.A., One Church: Two Indispensable Values: Protestant Principle and Catholic Substance (Dublin: Irish School of Ecumenics 1998), 9.

6. Paul Tillich, Systematic Theology, vol. 1 (Chicago: University of Chicago Press 1951), 37. 
the functions and organization of the church are not of ultimate concern (Tillich 1963, 208).

In this regard it is also interesting to note that, unlike many theologians today, Tillich was concerned about all social manifestations of the Christian church. Today it is rare to find theologians and church people who express their responsibility for the whole church, for the entire body of Christ. In tragically misunderstood ecumenical modesty, Christians in one church rarely feel called and motivated to offer prophetic and constructive criticism of developments in another church. Rather, every church mends its own fences and thus sinfully ignores its vocation to serve the development of the whole body of Christ. ${ }^{7}$ Moreover, such ecumenical modesty ignores the eschatological vocation of all Christians in this universe, whose future we share with all other human beings - women, men and children of different religious traditions or of no religious convictions at all. I shall have to come back to this universal aspect of Christian hope.

First, however, I wish to continue the discussion of different shapes of the Protestant principle in Tillich's Systematic Theology. For him the first and basic expression of the Protestant principle remains the principle of justification by grace through faith (Tillich 1963, 223). Yet he hastens to clarify that this concept has been interpreted differently throughout Christian history. Paul, Augustine, and Luther have stressed different aspects of the divine-human relationship when speaking of justification.

In Luther justification is the individual person's experience of both the divine wrath against his sin and the divine forgiveness which leads to a person-to-person relation with God without the cosmic and ecclesiastical framework of Paul or Augustine. This is the limitation in Luther's thought which has led both to an intellectual orthodoxy and to an emotional pietism. The subjective element was not counterbalanced in him (Tillich 1963, 227).

In modernity, Tillich argues, Luther's late medieval question "How do I find a merciful God?" was replaced by the question "How do I find meaning in a meaningless world?" (Ibid.)

Previously, in his famous book The Courage to Be (1952), Tillich had referred to the ontic anxiety of the classical period which had been longing to find stability of being, whereas the Middle Ages and the Reformation were predominantly concerned with salvation from

7. See in this respect also Werner G. Jeanrond "Glaubenskommunikation, Lehrnorm und Zensur", Kommunikation über Grenzen: Kongressband des XIII. Europäischen Kongresses für Theologie 21.-25. September 2008 in Wien, ed. Friedrich Schweitzer (Gütersloh: Gütersloher Verlagshaus 2009), 130-141 (140). 
sin leading to moral anxiety. Modernity, suffering from spiritual anxiety, seeks meaning. ${ }^{8}$ And, we might wish to add, that our own fragmented post-modern condition makes us long for genuine relationships in a world in which lasting relations have become rare. We suffer from relational anxiety. ${ }^{9}$

Hence, the meaning of justification depends to some extent on the concerns of the respective period in Christian history. However, in all periods this primary expression of the Protestant principle which "permeates every single assertion of the theological system" entails "that, in relation to God, God alone can act and that no human claim, especially no religious claim, no intellectual or moral or devotional 'work,' can reunite us with him" (Tillich 1963, 224). Like Barth, Tillich here defends God's creative and reconciling sovereignty, but unlike Barth, Tillich confesses this sovereignty in the midst of human culture and religion and in the midst of the respective ambiguities of what he has named "Catholic substance". Tillich concludes:

The Protestant principle is an expression of the conquest of religion by the Spiritual Presence and consequently an expression of the victory over the ambiguities of religion, its profanization, and its demonization. ... [It] is not restricted to the churches of the Reformation or to any other church; it transcends every particular church, being an expression of the Spiritual Community. It has been betrayed by every church, including the churches of the Reformation, but it is also effective in every church as the power which prevents profanization and demonization from destroying the Christian churches completely (Tillich 1963, 245).

The significance of Tillich's Protestant principle has also been stressed by Roman Catholic theologians, such as Gabriel Daly:

There have been Roman Catholics who complained that the Second Vatican Council brought Protestantism into the Catholic Church. To these complainants it is quite evident that this charge is enough to damn the council. They are correct in their recognition that the protestant principle had an important influence on the Second Vatican Council. They are sadly misled in not seeing the necessity of that influence (Daly 1998, 16).

8. Paul Tillich, The Courage to $B e, 2^{\text {nd }}$ ed (New Haven/London: Yale University Press 2000), 57-63.

9. See, for instance, Zygmunt Bauman, Liquid Love: On the Frailty of Human Bonds (Cambridge: Polity Press 2003). 
My question is now in what way the Protestant principle might be of help for Christians faced with the religious and theological challenges of our multireligious world.

\section{Interreligious Encounter and the Protestant Principle}

Karl Barth applied a form of the Protestant principle in order to challenge and overcome any manifestation of human religion and thus to free human beings to recognizing anew the sovereignty of God and God's grace. Paul Tillich was aware of the dialectics of the Protestant principle and the necessary embodiment and inculturation for any relationship between human beings and God. For Tillich the Protestant principle provides a star for successful Christian navigation in the realm of religion and culture.

When we look beyond the boundaries of Christian religion, we might appreciate that both Judaism and Islam are equally eager to articulate and defend their belief in the transcendence and sovereignty of God as well as in God's gracious offer of relationship to all people of good will. In a way, both of these religious traditions have developed even more stringent forms of the Protestant principle than Christianity. Their respective prophetic critique has stressed the singularity and unity of God against any attempt to engage in divine worship mediated by religious or cultural images and articulations. Sura 112, "Sincere Religion", for instance, reads: "In the name of God, the Merciful, the Compassionate. Say: 'He is God, One, God, the Everlasting Refuge, who has not begotten, and has not been begotten, and equal to Him is not any one." 10

At the same time, all three Abrahamic religions have consistently underlined the intimate relationship to which God has created and called women, men and children: God wants to be loved and God's mercy and compassion can be experienced in the here and now. The Shema Israel in Deuteronomy 6:4-6 illustrates this point: "Hear, O Israel: The LORD is our God, the LORD alone. You shall love the LORD your God with all your heart, and with all your soul, and with all your might. Keep these words that I am commanding you today in your heart." The synoptic gospels report how Jesus (Matt 22:37-40) vigorously confirmed this love commandment and linked it to that of Leviticus 19:18 "You shall love your neighbour as your-

10. The Koran Interpreted, trans. Arthur J. Arberry, Oxford World's Classics (Oxford: Oxford University Press 1998), 667. 
self" and 19:33: "You shall love the alien as yourself". ${ }^{11}$ Also the Koran refers to the mutual love relationship between sovereign God and his people, for example, in Sura 5, 59 (The Koran 1998, 109).

Hence, all three Abrahamic religions promote an intimate covenantal relationship between God and human beings while at the same time emphasizing God's transcendence and sovereignty, though in different and shifting degrees of radicality. The dialectics between God's transcendence and the experience of God's presence in this universe, though common to all three religions, has found changing expressions in each one of them - at times as a consequence of their factual encounter with the other and the resulting philosophical and theological cross-fertilization. Aristotelian thinking, for instance, was made available both to medieval Jewish and Christian theologians through their respective encounter with Islamic intellectuals. Maimonides provides a good example for such an interreligiously inspired rethinking of God's absolute transcendence. ${ }^{12}$

It thus can be argued that the Protestant principle is not a purely Christian concern. Rather, even within the framework of interreligious encounter it is able to offer a way to concentrate anew on God's radical transcendence and sovereignty, on the one hand, and on God's gracious offer of relationship to human beings, on the other hand. Here I have only been able to point to the encounter among Abrahamic religions. However, this principle may also be useful when exploring the encounter between these and other religious traditions.

Appreciating the prominence and significance of this principle both inside and outside of Christian praxis may also help us to pay critical and self-critical attention to other aspects of our tradition which we have been accustomed to regard as our own Christian invention and property as is the case, for example, with love. Martin Luther and countless theologians after him have spoken of "Christian love". ${ }^{13}$ But is love genuinely Christian, can love ever be only Christian? Should not all manifestations of love be approached and scrutinized with the help of the Protestant principle? What I have in mind is this: God's gift of love to humanity cannot be exclusively claimed by Christians. Rather, the Christian praxis of love has been made

11. All Bible quotations are taken from The Holy Bible: New Revised Standard Version (New York/Oxford: Oxford University Press 1989).

12. Cf. Gerold Necker, "Gott: IX.: Judentum. 2 Mittelalter und Neuzeit", Religion in Geschichte und Gegenwart, 4th ed, vol. 3 (Tübingen: Mohr Siebeck 2000), 1136-1138 (1136).

13. For a more detailed discussion and references see Werner G. Jeanrond, $A$ Theology of Love (London/New York: T\&T Clark 2010), 96-103. 
possible through the proclamation of God's gift of love before, in and beyond the Christian church. Hence, in his ministry, death and resurrection Jesus Christ has confirmed the logic and extent of divine love and he has reissued the divine invitation to all human beings to love God, each other, God's universe and their own emerging selves. The witness of Jesus Christ and of his disciples to this divine gift and to its dynamic and transformative potential does not make this gift a possession of the church. Rather it places the church anew under the sovereign rule of God's creating and reconciling love. Hence, the Protestant principle redirects the church's perspective for God's universal sovereignty and creative and reconciling activity. How could we Christians engage in the praxis of love when we fail to recognize the divinely ordained universal horizon of all genuine love?

\section{Protestant Principle and Christian Hope}

In his recent book Eschatology and Hope, the Australian theologian Anthony Kelly has reminded Christians of the need to see all of their hopes liberated by hope. "Christian hope is always more than the catalogue of particular hopes, for it looks to an incalculable fulfilment in terms of what can never be fully expressed."14 Although Kelly does not explicitly refer to the Protestant principle, it is clear that all of our hopes need to be submitted to the sovereignty of God and liberated in this encounter between God and the different embodiments of our hopes, i.e. with "Catholic substance":

In this regard, the church is the community of those who have a sense of a future so full of promise, so absolute, that nothing and no one is excluded. Christians, as people of God, are the people of hope. They are called to witness to the great transformation now afoot which promises the liberation of all human hopes to their fullest dimensions. Yet it is not as though Christian hope occupies some deathless standpoint, untroubled by the agonies of the world and invulnerable to its sufferings. The life of hope is not a matter of watching in armchair comfort a replay of the highlights once "our team" has won (Kelly 2006, 13).

Against any form of tribalism in eschatology Kelly proposes the need for an inter-hope dialogue. "A new openness or sympathy comes into play when the encounter between different faiths and spiritualities is set within a horizon of hope and its expectation of an ultimate communion in eternal life. Inter-hope dialogue would highlight the un- 
imaginable 'otherness' of eschatological fulfilment." (Kelly 2006, 16) Kelly does not propose to abandon the particular Christian experiences of God's giving of his own son. Rather he recognizes the tension between two poles: this christological aspect of hope and the universality of God's saving will. For Kelly inter-hope dialogue is "a matter of all looking toward a promised future of communion in eternal life" (Kelly 2006, 17).

These brief references to the tension between eschatological substance and Protestant principle must suffice here. In spite of the necessary condensation of my argument I hope to have shown that any approach to continuing church renewal, guided by the Protestant principle, must acknowledge not only the radical nature of this principle, but also its challenge to any model of Christian community formation in this universe. The programmatic formula Ecclesia semper reformanda is the result of the application of the Protestant principle on all manifestations and models of church.

We need not fear our own religious, cultural and political embodiments in this universe, nor do we have reason to fear the encounter with other religions in our globalizing world. The Protestant principle offers us a compass even in troubled times. For it reminds us of both God's radical transcendence and God's gracious care for and presence in this universe and with each woman, man and child. Thus, we can respond to God's invitation to help building God's coming reign already here and now without fear of losing direction. 